\title{
LKPD Bentuk Molekul Berbasis Inkuiri Terstruktur Dengan Menggunakan Pemodelan Tiga Dimensi
}

\section{Student Worksheets of Molecular Shape Topic Based on Structured Inquiry with 3-D Models Usage}

\author{
Nurafni ${ }^{1}$ and M Azhar ${ }^{1 *}$ \\ ${ }^{1}$ Pendidikan Kimia, Universitas Negeri Padang, Jl. Prof. Dr. Hamka, Air Tawar Barat, \\ Padang Utara, Sumatera Barat, Indonesia 25171 \\ *minda@fmipa.unp.ac.id
}

ARTICLE INFO

Received 16 October 2019

Revised 20 October 2019

Published 21 October 2019

\begin{abstract}
This study is research and development (R\&D) and using 4-D models, but disseminate step is not done. Validation of student worksheets has been done by chemistry lecturers and chemistry teachers. The practicality of student worksheets has been done by chemistry teachers and students of $2^{\text {nd }}$ grade of SMAN 1 Pariaman. The result showed that moment kappa average of validity was 0,83 with very high validity category and moment kappa average of practicality were 0,9 by chemistry teachers and 0,86 by students with very high category. Therefore student worksheets of molecular shape based on structured inquiry with emphasis on the submicroscopic level using 3-D models is valid and practice to be used on the chemistry learning.
\end{abstract}

\section{KEYWORDS}

Student Worksheets, Molecular Shape, Structured Inquiry, Submicroscopic Level, 3-D Models.

\begin{abstract}
ABSTRAK
Jenis penelitian ini merupakan penelitian dan pengembangan (R\&D) dan menggunakan model pengembangan 4 - $\mathrm{D}$, tetapi tahap disseminate tidak dilakukan. Uji validitas LKPD dilakukan oleh dosen kimia FMIPA UNP dan guru kimia. Sedangkan uji praktikalitas LKPD dilakukan oleh guru kimia dan peserta didik kelas 2 SMAN 1 Pariaman. Hasil penelitian menunjukkan bahwa rata-rata momen kappa uji validitas adalah 0,83 dengan kategori sangat tinggi dan rata-rata momen kappa uji praktikalitas adalah 0,9 oleh guru kimia dan 0,86 oleh peserta didik dengan kategori sangat tinggi. Oleh karena itu, LKPD bentuk molekul berbasis inkuiri terstruktur dengan penekanan pada level submikroskopik menggunakan pemodelan tiga dimensi telah valid dan praktis digunakan dalam pembelajaran kimia.
\end{abstract}

\section{KATA KUNCI}

LKPD, Bentuk Molekul, Inkuiri Terstruktur, Level Submikroskopik, Pemodelan Tiga Dimensi 


\section{PENDAHULUAN}

Materi bentuk molekul merupakan salah materi pelajaran kimia kelas $\mathrm{X}$ semester ganjil yang mempelajari tentang susunan tiga dimensi dari atom-atom dalam molekul. Salah satu cara meramalkan bentuk molekul adalah berdasarkan teori VSEPR. Bentuk molekul sangat penting dipelajari karena dapat mempengaruhi kepolaran dari suatu molekul ${ }^{[1]}$. Materi bentuk molekul merupakan materi yang bersifat abstrak sehingga dapat menimbulkan kesulitan pada peserta didik ${ }^{[2]}$.

Berdasarkan hasil wawancara dengan salah seorang guru kimia di SMAN 1 Pariaman diketahui bahwa sebagian peserta didik masih kesulitan dalam mempelajari bentuk molekul. Peserta didik kesulitan dalam menghubungkan struktur Lewis dan susunan tiga dimensi molekul ${ }^{[3]}$. Selain itu, bentuk molekul merupakan materi yang membutuhkan imajinasi tinggi ${ }^{[4]}$. Pembelajaran yang menekankan pada level submikroskopik akan membantu peserta didik dalam mempelajari bentuk molekul.

Level submikroskopik merupakan salah satu representasi kimia. Level submikroskopik mempelajari konsep-konsep tentang partikel materi yang tidak dapat dilihat dalam kehidupan nyata $^{[5]}$. Level submikroskopik merupakan level yang paling sulit dipahami peserta $\operatorname{didik}^{[6]}$. Kemampuan peserta didik dalam menyelesaikan permasalahan kimia akan meningkat seiring dengan bertambahnya pemahaman pada level submikroskopik ${ }^{[7]}$. Pemahaman bentuk molekul pada tingkat submikroskopik dapat dibantu dengan menggunakan alat bantu belajar atau media yang dapat memberikan gambaran kongkrit kepada peserta didik sehingga belajar bentuk molekul bukan hanya sekedar menghafal tetapi lebih dari memahami konsep bentuk molekul secara menyeluruh ${ }^{[8]}$. Untuk mengatasi permasalahan tersebut, dibutuhkan media pembelajaran yang dapat menarik minat peserta didik yaitu pemodelan.

Pemodelan berasal dari kata model yaitu representasi sederhana dari sesuatu yang nyata, tetapi tidak dapat dilihat secara langsung oleh peserta didik. Beberapa jenis model yang dapat digunakan diantaranya adalah animasi komputer, magnet bar, molimod, serta bola dan tongkat $t^{[9]}$. Berdasarkan pada pengamatan dibeberapa sekolah khususnya di daerah, ketersediaan model masih sangat terbatas dan model yang tersedia di sekolah biasanya molimod. Hanya saja molimod yang tersedia di sekolah-sekolah jumlahnya terbatas dan molimod yang ada belum dapat menggambarkan konsep utuh tentang bentuk molekul. Contoh permasalahan tersebut adalah untuk bentuk molekul segitiga bipiramida dan oktahedral, karena molimod yang ada hanya menjelaskan sampai bentuk molekul tetrahedral.

Berdasarkan kenyataan tersebut, perlu dikembangkan model dari bola-bola untuk molekul segitiga bipiramida dan oktahedral agar dapat mengatasi kekurangan dari molimod sehingga dapat menggambarkan konseputuh bentuk molekul. Selain itu menggunakan model tiga dimensi pada materi bentuk molekul berdasarkan teori VSEPR dapat memudahkan peserta didik dalam mempelajari bentuk molekul yang abstrak atau tidak dapat dilihat oleh mata telanjang ${ }^{[10]}$. Pemahaman bentuk molekul pada tingkat submikroskopik dengan pemodelan dapat diterapkan dengan bahan ajar.

Bahan ajar adalah sumber belajar yang digunakan untuk mencapai keberhasilan peserta didik dalam belajar. Lembar Kerja Peserta Didik (LKPD) merupakan salah satu jenis bahan ajar yang sering digunakan. LKPD adalah bahan ajar yang menekankan pada aspek pengalaman peserta didik dengan dibantu guru sebagai fasilitator ${ }^{[11]}$. LKPD bertujuan sebagai sumber belajar yang meningkatkan pemahaman peserta didik melalui soal latihan terhadap materi yang diajarkan ${ }^{[12]}$.

Inkuiri merupakan salah satu model pembelajaran Kurikulum 2013 yang dapat melatih peserta didik dalam menemukan konsep. Berdasarkan bimbingan guru dalam proses pembelajaran, inkuiri dibagi menjadi empat level, yaitu inkuiri terbuka, inkuiri terbimbing, inkuiri terstruktur dan inkuiri konfirmasi ${ }^{[13]}$. Pada inkuiri terstruktur guru menyajikan permasalahan, pertanyaan dan prosedur sehingga peserta didik dapat mengumpulkan data dan menganalisisnya serta membuat kesimpulan ${ }^{[14]}$. Model inkuiri terstruktur memiliki empat sintak pembelajaran yang meliputi observasi, membuat hipotesis, koleksi dan organisasi data serta membuat kesimpulan dari permasalahan yang diberikan ${ }^{[15]}$. Penelitian sebelumnya menyatakan bahwa pembelajaran menggunakan LKS berbasis inkuiri terstruktur dapat membantu peserta didik dalam memahami konsep serta memperoleh hasil belajar yang lebih baik $^{[16]}$. Selain itu peserta didik berpartisipasi aktif dalam diskusi kelompok dan hasil belajar peserta didik meningkat melalui pembelajaran yang menggunakan model inkuiri terstruktur ${ }^{[17]}$.

Berdasarkan permasalahan di atas, maka diperlukan pengembangan LKPD bentuk molekul berbasis inkuiri terstruktur dengan penekanan pada level submikroskopik menggunakan pemodelan tiga dimensi. Penelitian ini bertujuan untuk mengembangkan LKPD bentuk molekul yang valid dan praktis digunakan pada pembelajaran kimia kelas X SMA.

\section{METODE}

Jenis penelitian ini yaitu Research and Development (R\&D) yang merupakan suatu penelitian untuk mengembangkan produk baru atau memperbaharui produk yang sudah ada ${ }^{[18]}$. Model 4-D merupakan salah satu model pengembangan yang terdiri atas tahapan define, design, develop dan disseminate. Penelitian pengembangan LKPD bentuk molekul berbasis inkuiri tertsruktur dilakukan sampai tahap develop yaitu uji validitas dan praktikalitas. Subjek dalam penelitian ini adalah 3 orang dosen kimia FMIPA UNP, 2 orang 
guru kimia dan 31 peserta didik kelas XI MIPA 7 SMAN 1 Pariaman. Rumus yang digunakan untuk menghasilkan data yaitu momen Kappa Cohen dimana:

$$
\text { momen kappa }(\kappa)=\frac{\rho_{0}-\rho_{\varepsilon}}{1-\rho_{\varepsilon}}
$$

Keterangan :

$k=$ momen kappa yang menunjukkan validitas produk

$\rho o=$ proporsi yang terealisasi, dihitung dengan cara jumlah nilai yang diberi validator dibagi dengan jumlah nilai maksimal

$\rho \mathrm{e}=$ proporsi yang tidak terealisasi dihitung dengan cara jumlah nilai maksimal dikurangi dengan jumlah nilai total yang diberi validator dibagi jumlah nilai maksimal

Tabel 1. Kategori keputusan berdasarkan momen kappa (k)

\begin{tabular}{c|c} 
Interval & Kategori \\
\hline $0,81-1,00$ & Sangat tinggi \\
\hline $0,61-0,80$ & Tinggi \\
\hline $0,41-0,60$ & Sedang \\
\hline $0,21-0,40$ & Rendah \\
\hline $0,01-0,20$ & Sangat rendah \\
\hline$<0,00$ & Tidak valid
\end{tabular}

Pada penelitian ini digunakan instrumen angket validitas dan praktikalitas, untuk dosen kimia FMIPA UNP dan guru kimia diberikan angket validitas, sedangkan untuk guru kimia dan peserta didik diberikan angket praktikalitas. Setelah LKPD bentuk molekul berbasis inkuiri terstruktur divalidasi, kemudian LKPD tersebut direvisi sesuai kritikan dan masukan dari validator. Setelah direvisi, dilakukan uji praktikalitas LKPD untuk mengetahui kepraktisan LKPD yang dikembangkan.

\section{HASIL DAN DISKUSI}

\subsection{Tahap define}

\subsubsection{Analisis awal-akhir}

Pada tahap ini dilakukan wawancara dengan salah seorang guru kimia dan 33 orang peserta didik SMAN 1 Pariaman. Hasil dari analisis awalakhir ditemukan bahwa sebagian peserta didik masih kesulitan untuk memahami materi bentuk molekul. Bentuk molekul merupakan materi yang bersifat abstrak, sehingga peserta didik harus memiliki keterampilan berpikir tingkat tinggi untuk memahami konsep ${ }^{[9]}$. Sementara dalam pengamatan yang dilakukan, sebagian peserta didik masih menggunakan metode penghafalan. Guru juga menyatakan telah menggunakan lembar kerja peserta didik dan demonstrasi model dari plastisin. LKPD yang sudah ada memuat soal-soal, belum memiliki gambar yang berwarna, dan demostrasi yang dilakukan hanya di depan kelas dan tidak dimuat dalam LKPD. LKPD yang digunakan belum memberikan penguatan konsep dan motivasi belajar pesertadidik. Oleh sebab itu dirancang LKPD bentuk molekul berbasis inkuiri terstruktur dengan penekanan pada level submikroskopik menggunakan pemodelan tiga dimensi untuk membantu peserta didik dalam memahami konsep pembelajaran serta meningkatkan aktifitas, minat dan motivasi peserta didik dalam belajar.

\subsubsection{Analisis peserta didik}

Hasil wawancara dengan guru kimia kimia kelas X didapatkan informasi bahwa kemampuan akademis dan minat belajar peserta didik pada pembelajaran materi bentuk molekul termasuk sedang. Berdasarkan teori Piaget mengenai tahap perkembangan anak, peserta didik yang berumur $>12$ tahun telah memiliki kemampuan berpikir tingkat tinggi. Pemahaman peserta didik pada level submikroskopik dari materi bentuk molekul membutuhkan pemodelan tiga dimensi untuk memvisualisasikan sifat abstrak dari materi tersebut. Selain itu, diperlukan suatu model pembelajaran yang dapat mempertajam kemampuan dan keterampilan berpikir peserta didik. Inkuiri terstruktur merupakan model pembelajaran yang melibatkan peserta didik dalam penemuan sehingga peserta didik berpatisipasi aktif dalam diskusi kelompok. Pembelajaran berbasis inkuiri terstruktur menggunakan pemodelan tiga dimensi dapat diterapkan dalam sebuah LKPD yang dilengkapi dengan gambar dan warna menarik.

\subsubsection{Analisis tugas}

Pada tahap ini dilakukan analisis pada Kompetensi Dasar (KD) berdasarkan kurikulum 2013 revisi 2018. Kompetensi Dasar materi bentuk molekul yang harus dikuasai oleh peserta didik yaitu KD 3.6 Menentukan bentuk molekul dengan menggunakan teori tolakan pasangan elektron kulit valensi (VSEPR) atau Teori Domain Elektron. Kompetensi tersebut dijabarkan menjadi beberapa Indikator Pencapaian Kompetensi (IPK) yaitu; 1) menuliskan Lewis dengan benar melalui contoh yang diberikan; 2) meramalkan bentuk molekul dengan benar melalui pemodelan; 3) menganalisa pengaruh tolakan pasangan elektron bebas atom pusat terhadap besar sudut ikatan dan bentuk molekul melalui pemodelan; 4) mengaitkan bentuk molekul berdasarkan teori tolakan pasangan elektron di sekitar inti atom dengan kepolaran senyawa.

\subsubsection{Analisis konsep}

Konsep-konsep yang terdapat pada materi bentuk molekul disusun hirarki menjadi peta konsep. Konsep-konsep tersebut dianalisis berdasarkan buku-buku kimia universitas dan bukubuku kimia SMA. Beberapa konsep tersebut adalah struktur Lewis, elektron valensi, teori VSEPR, domain elektron, domain elektron ikatan, domain elektron bebas, sudut ikatan, linear, trigonal planar, 
tetrahedral, trigonal bipiramida, oktahedral, bentuk $\mathrm{V}$, bentuk $\mathrm{T}$.

\subsubsection{Analisis tujuan pembelajaran}

Tujuan pembelajaran materi bentuk molekul yaitu melalui model pembelajaran inkuiri terstruktur dengan menggali informasi dari berbagai sumber belajar, melakukan penyelidikan sederhana dan mengolah informasi, peserta didik diharapkan terlibat aktif selama proses belajar mengajar yang sedang berlangsung, memiliki sikap ingin tahu, teliti dalam melakukan pengamatan, bertanggung jawab dalam menyampaikan pendapat, menjawab pertanyaan, memberi saran dan kritik, serta mampu menuliskan struktur Lewis, meramalkan bentuk molekul, menganalisa pengaruh tolakan pasangan elektron bebas atom pusat terhadap besar sudut ikatan dan bentuk molekul, serta mengaitkan bentuk molekul dengan kepolaran senyawa.

\subsection{Tahap Design}

Tujuan tahap design adalah untuk mendesain LKPD bentuk molekul berbasis inkuiri terstruktur yang dikembangkan. Tahap perancangan ini sesuai dengan hasil angket peserta didik SMAN 1 Pariaman yang mana peserta didik menginginkan LKPD yang mudah dipahami, memiliki gambar dan warna yang menarik serta dilengkapi dengan pemodelan. LKPD bentuk molekul disusun berdasarkan beberapa komponen sebagai berikut: 1) cover; 2) kata pengantar; 3) daftar isi; 4) daftar gambar; 5) petunjuk penggunaan LKPD; 6) kompetensi inti; 7) kompetensi dasar; 8) indikator pencapaian kompetensi; 9) tujuan pembelajaran; 10) peta konsep; 11) pendahuluan; 12) lembar kegiatan; 13) lembar kerja; 14) evaluasi. Cover dan lembar kegiatan dapat dilihat pada Gambar 1 dan Gambar 2.

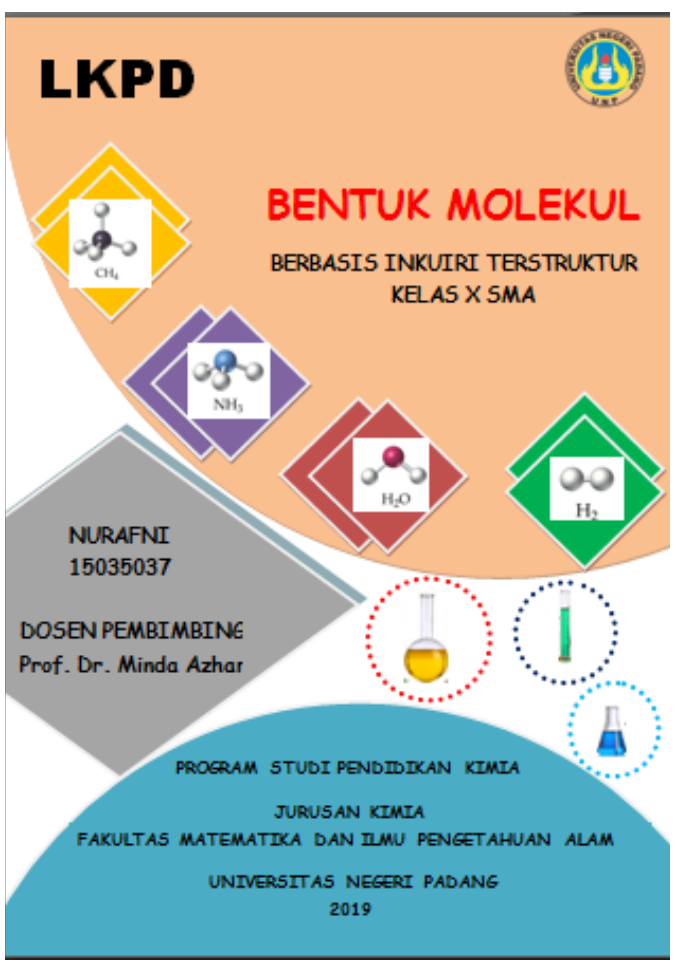

Gambar 1. Cover
Bagian cover LKPD dirancang dengan warna yang menarik untuk dapat menimbulkan motivasi belajar peserta diidk dalam proses pembelajaran. Cover LKPD juga dilengkapi dengan gambar yang berhubungan dengan materi bentuk molekul. Lembar kegiatan peserta didik berisi materi bentuk molekul yang disusun berdasarkan tahapantahapan dalam inkuiri terstruktur yang meliputi tahap observasi, hipotesis, koleksi dan organisasai data, dan kesimpulan.

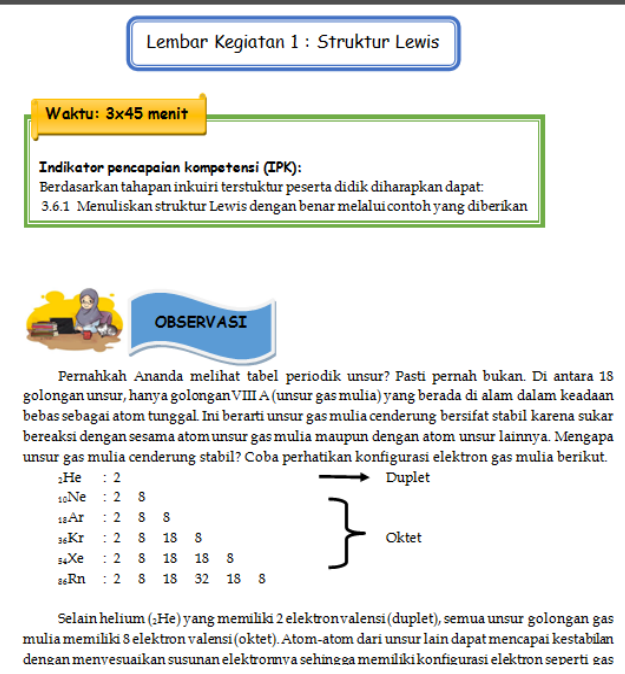

Gambar 2. Lembar Kegiatan

\subsection{Tahap develop}

\subsubsection{Uji validitas}

Tujuan dilakukan uji validitas adalah untuk mengukur tingkat kevalidan dari LKPD yang telah dikembangkan. Validator merupakan pakar atau tenaga ahli yang memiliki pengetahuan untuk menilai LKPD bentuk molekul berbasis inkuiri terstruktur yang dikembangkan ${ }^{[19]}$. Pada penelitian ini ini, peneliti menggunakan 5 orang validator yang terdiri dari 3 orang dosen kimia FMIPA UNP dan 2 orang guru kimia SMAN 1 Pariaman. Hasil yang diperoleh pada uji validasi LKPD bentuk molekul dapat dilihat pada Gambar 3.

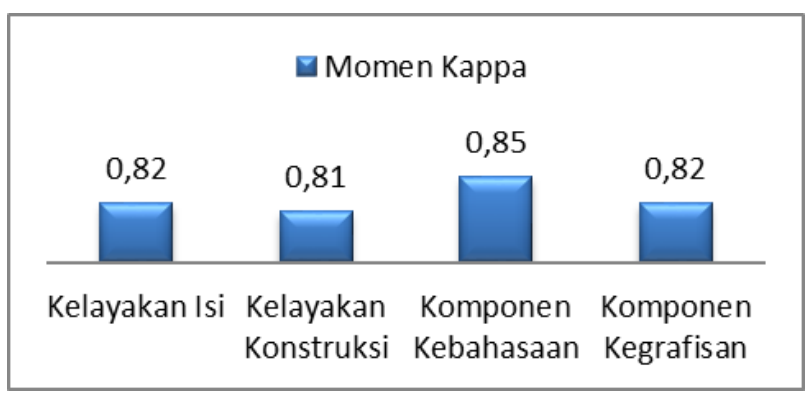

Gambar 3. Hasil analisis data validasi oleh 5 orang validator

Komponen kelayakan isi pada LKPD bentuk molekul berbasis inkuiri terstruktur memiliki nilai momen kappa 0,82 dengan kategori sangat tinggi. Dengan demikian LKPD bentuk molekul berbasis inkuiri terstruktur yang dikembangkan telah valid dan sesuai dengan tuntutan kompetensi dasar. Selain 
itu, penyajian materi dalam LKPD juga telah sesuai dengan model yang digunakan dan kalimat dalam LKPD telah menekankan pada level submikroskopik sehingga dapat membimbing peserta didik dalam memahami konsep bentuk molekul.

Komponen penyajian pada LKPD bentuk molekul berbasis inkuiri terstruktur memiliki nilai momen kappa 0,81 dengan kategori sangat tinggi. Dengan demikian LKPD bentuk molekul berbasis inkuiri terstruktur yang dikembangkan telah disusun secara sistematik sesuai dengan komponen-komponen penyusunan LKPD, mulai dari judul, KI, KD, IPK, tujuan pembelajaran dan model inkuiri terstruktur yang digunakan telah disusun berdasarkan tahapan belajar inkuiri terstruktur. Pembelajaran menggunakan inkuri terstruktur dapat memudahkan peserta didik dalam menemukan konsep melalui kegiatan penyelidikan secara langsung ${ }^{[15]}$.

Komponen kebahasaan pada LKPD bentuk molekul berbasis inkuiri terstruktur memiliki nilai momen kappa 0,85 dengan kategori sangat tinggi. Dengan demikian LKPD bentuk molekul berbasis inkuiri terstruktur yang dikembangkan telah menggunakan bahasa yang benar dan sesuai dengan aturan penulisan. Selain itu, pertanyaan dalam LKPD diajukan secara jelas yang menggunakan simbol/lambang secara konsisten.

Komponen kegrafisan pada LKPD bentuk molekul berbasis inkuiri terstruktur memiliki nilai momen kappa 0,82 dengan kategori sangat tinggi. Dengan demikian LKPD bentuk molekul berbasis inkuiri tertsruktur telah memuat gambar dan penggunaan font yang dapat diamati dan dibaca dengan jelas serta pemilihan warna yang dapat menarik perhatian peserta didik.

Momen kappa dari keempat komponen memiliki rata-rata 0,83 dengan kategori kevalidan sangat tinggi. Berdasarkan kategori tersebut, maka LKPD bentuk molekul berbasis inkuiri terstruktur dengan penekanan pada level submikroskopik menggunakan pemodelan tiga dimensi sudah dapat digunakan untuk pembelajaran di kelas X SMA.

\subsubsection{Revisi}

Tahap revisi bertujuan memperbaiki bagian LKPD yang dinilai kurang tepat oleh validator sebelum dilakukan uji coba. Perbaikan yang dilakukan terhadap LKPD ini sebagai berikut: 1) Memperbaiki cover; 2) Bagian koleksi dan organisasi data, tambahkan satu langkah untuk peserta didik merangkai model; 3) Menambahkan manfaat senyawa yang dicontohkan.

\subsubsection{Uji Praktikalitas}

Pada tahap uji praktikalitas diperoleh data uji kepraktisan melalui angket praktikalitas yang dinilai oleh 2 orang guru kimia dan 31 peserta didik kelas XI SMAN 1 Pariaman. Hasil analisis data praktikalitas oleh guru dan peserta didikterhadap LKPD bentuk molekul berbasis inkuiri tertsruktur dengan penekanan pada level submikroskopik menggunakan pemodelan tiga dimensi dapat dilihat pada Gambar 4.

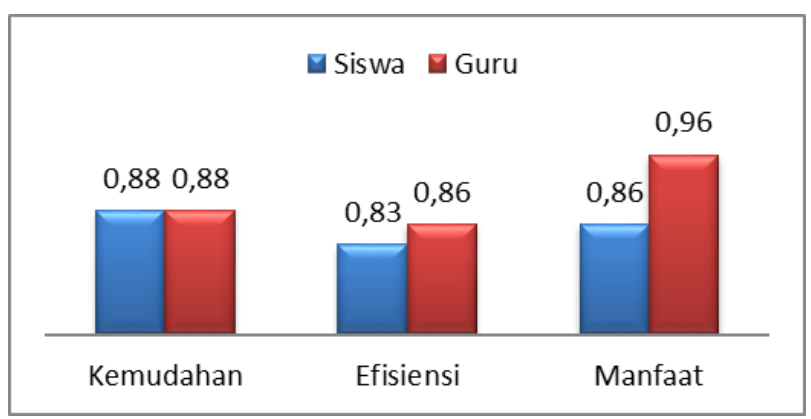

Gambar 4. Hasil analisis data praktikalitas LKPD

bentuk molekul oleh guru dan peserta didik

Berdasarkan grafik di atas diperoleh hasil analisis data penilaian praktikalitas LKPD bentuk molekul berbasis inkuiri terstruktur masingmasing komponen yaitu: 1) komponen kemudahan penggunaan LKPD bentuk molekul memiliki nilai momen kappa 0,88 oleh guru dan peserta didik dengan kategori sangat tinggi; 2) komponen efisiensi waktu LKPD bentuk molekul memiliki nilai momen kappa 0,86 oleh guru dan 0,83 oleh peserta didik dengan kategori sangat tinggi; 3) komponen manfaat LKPD bentuk molekul memiliki nilai momen kappa 0,96 oleh guru dan 0,86 oleh peserta didik dengan kategori sangat tinggi.

Hasil rata-rata uji praktikalitas LKPD bentuk molekul adalah 0,9 oleh guru dan 0,86 oleh peserta didik dengan kategori kepraktisan sangat tinggi. Dengan demikian LKPD bentuk molekul yang dikembangkan dapat membantu pembelajaran lebih efisien dan membuat peserta didik menjadi lebih tertarik dan termotivasi untuk belajar. Selain itu LKPD yang dikembangkan dapat membantu guru untuk membimbing peserta didik menemukan konsep dan latihan-latihan yang ada dalam LKPD dapat melatih keterampilan berpikir peserta didik. Berdasarkan ketiga komponen yang telah dinilai, LKPD bentuk molekul berbasis inkuiri terstruktur dengan penekanan pada level submikroskopik menggunakan pemodelan tiga dimensi untuk kelas X SMA sudah praktis dan dapat digunakan di sekolah.

\section{SIMPULAN}

Berdasarkan tujuan penelitian, dapat disimpulkan bahwa LKPD bentuk molekul berbasis inkuiri terstruktur dengan penekanan pada level submikroskopik menggunakan pemodelan tiga dimensi untuk kelas X SMA memiliki tingkat kevalidan dan kepraktisan yang sangat tinggi.

\section{REFERENSI}

1. R. Chang and J. Overby, General Chemistry The Essential Concepts, 6nd ed., New York: McGraw-Hill Companies, 2011.

2. Indiatiningsih, "Penggunaan Media Plastisin Untuk Meningkatkan Hasil Belajar Kognitif Siswa Materi Bentuk Molekul Kelas X Lintas Minat di SMAN 8 MALANG," Zarah, vol. 5, no. 
1, pp. 5-13, 2017.

3. K. I. Donaghy and K. I. Saxton, "Connecting Geometry and Chemistry: A Three-Step Approach to Three-Dimensional Thinking," Journal of Chemical Education, vol. 89, pp. 917920,2012.

4. A. W. Sabekti, H. R. Widarti and Mahmudi, "Analisis Pemahaman Konsep Siswa Kelas XI IPA SMAN 1 MALANG pada Topik Bentuk Molekul," Universitas Negeri Malang, 2011.

5. D. F. Treagust, G. Chittleborough and T. L. Mamiala, "The role of submicroscopic and symbolic," International Journal of Science Education, vol. 25, no. 11, pp. 1353-1368, 2003.

6. K. Anwar, Sunyono and N. Kadaritna, "Pembelajaran Model Simayang Tipe II Untuk Meningkatkan Model Mental Dan Penguasaan Konsep," Jurnal Pendidikan dan Pembelajaran Kimia, vol. 3, pp. 705-806, 2015.

7. Sunyono, L. Yuanita and M. Ibrahim, "Efektivitas Model Pembelajaran Berbasis Multiple Representasi Dalam Membangun Model Mental Mahasiswa Topik Stoikiometri Reaksi," Pendidikan Progresif, vol. 3, no. 1, pp. 65-79, 2013.

8. N. Supriono and F. Rozi, "Pengembangan Media Pembelajaran Bentuk Molekul Kimia Menggunakan Augmented Reality Berbasis Android," Jurnal Ilmiah dan Pembelajaran Informatika, vol. 3, no. 01, pp. 53-61, 2018.

9. Sutrisno, S. Poedjiastoeti and I. G. M. Sanjaya, "Efektifitas Pembelajaran Bentuk Molekul dengan Pemodelan Real Berbasis Penemuan Terbimbing untuk Melatihkan Keterampilan Berpikir Tingkat Tinggi Siswa," Pendidikan Sains Pascasarjana Universitas Negeri Surabaya, vol. 3, no. 2, 2014.

10. K. Wuttisela, "Authentic Assessment Tool for the Measurement of Students' Understanding of the Valence Shell Electron Pair Repulsion Theory," Universal Journal of Educational Research, vol. 5, no. 9, pp. 1549-1553, 2017.

11. P.N.Kementerian, Juknis Pengembangan Bahan Ajar SMA, Jakarta: Direktorat Pembinaan SMA, 2010.

12. B. Mizarwan, Ratnawulan and Gusnedi, "Pengaruh Lembar Kerja Peserta Didik Berorientasi Inkuiri Terbimbing Terhadap Kompetensi IPA Kelas VII SMPN 2 BUKITTINGGI," PILLAR OF PHYSICS EDUCATION, vol. 6, pp. 41-48, 2015.

13. H. Banchi and R. Bell, "The Many Levels of Inquiry," Science and Children, vol. 46 (2), pp. 26-29, 2008.

14. A. Colburn, "An Inquiry Primer," Sciencescope, 2000.

15. M. Zion and R. Mendelovici, "Moving From Stuctured to Open Inquiry: Challenges and Limits," Science Education International, vol. 23, no. 4, pp. 383-399, 2012.

16. A. M. Maryati, Y. Sunarya and K., "Lembar Kerja Siswa (LKS) Eksperimen dan Non-Eksperimen
Berbasis," Prosiding Simposium Nasional Inovasi dan Pembelajaran Sains 2015, 2015.

17. Sugiarto, "Peningkatan Hasil Belajar materi Getaran dan Gelombang Melalui Pembelajaran Berbasis Inkuiri Terstruktur," Jurnal Penelitian Tindakan Kelas, vol. 16, no. 4, 2015.

18. Sugiyono, Metode Penelitian Pendidikan, Bandung: Alfabeta, 2012.

19. Sukardi, Evaluasi Pendidikan, Prinsip, dan Operasionalnya, Yogyakarta: Bumi Aksara, 2011. 